\author{
International Journal of Economics, Business and Accounting Research (IJEBAR) \\ Peer Reviewed - International Journal \\ Vol-4, Issue-2, 2020 (IJEBAR) \\ E-ISSN: 2614-1280 P-ISSN 2622-4771 \\ https://jurnal.stie-aas.ac.id/index.php/IJEBAR
}

\title{
THE AUDIT PROCESS IN COMPANIES THAT IMPLEMENT SOFTWARE ENGINEERING PROJECTS
}

\author{
Rafael Mellado Silva1, Antonio Faúndez-Ugalde 2, María Blanco Lobos 3 \\ 1,2,3Escuela de Comercio, Pontificia Universidad Católica de Valparaíso, Chile \\ https://orcid.org/0000-0002-6143-2929 1) \\ E-mail: rafael.mellado@pucv.cl
}

\begin{abstract}
The use of technological resources and software has become standardized in today's society, which is why there is a need to be able to update according to the requirements that the market and industry demand from companies that develop products through a software engineering process. The role of the auditor is extremely important since he is the one who must make sure that everything is controlled and that the required needs are being fulfilled, as well as he is concerned about the security of the entities and their internal background. In this context, it is necessary to constantly improve the auditor's procedures and the legislation that regulates them, since the multiple frauds that companies suffer in terms of information obtained easily and quickly, without any major control, are well known, and it is here where care must be taken in order to reduce the levels of violations of access to unauthorized information assets. The objective of this paper is to present everything that surrounds the process of auditing requirements of software engineering projects, both generically and specifically in projects in particular the financial area, generally covering everything that is present in a software engineering project considering the need, what is obtained from them and why they arise in organizations.
\end{abstract}

Keywords: $\quad$ Software, Software engineering, software audit, software requirements

\section{Introduction}

With the new era of technology, computer systems begin to be developed with the objective of processing information at a systematic level that brings about different changes in the organizations, either by streamlining processes or by guarding their information, generating alterations at the different levels and internal structure (Esterkin et al., 2017; Isasi-Genix et al., 2012; Quesada Sevilla et al., 2016; Razón et al., 2014). At a financial-accounting level, the impact is very great since decisions are made based on this and it is very important that it is working correctly. Therefore, constant controls and tests are made to avoid fraud or scams, in addition to guaranteeing the quality of the organization, seeking efficiency and effectiveness in each phase of its operations (Hammi, 2014; Marín Sánchez and Lugo García, 2016). This is why new methods for auditors arise when managing software engineering processes, which are updated as the needs and requirements of organizations change. Due to this, we will carry out an investigation focusing on requirements and software projects, pointing out sections with their characteristics, legal framework, their impact at a national level in Chile, as well as indicating real examples on auditing and the application of software projects 


\section{International Journal of Economics, Business and Accounting Research (IJEBAR) Peer Reviewed - International Journal Vol-4, Issue-2, 2020 (IJEBAR) \\ E-ISSN: 2614-1280 P-ISSN 2622-4771 \\ https://jurnal.stie-aas.ac.id/index.php/IJEBAR}

\section{Conceptual Framework}

\subsection{Business Technological Evolution}

The information technology in today's organizations comes from a long history that begins with the great civilizations which had the need to know the income and expenses using papyrus as an agenda to record the accounting, as the years go by in the beginning of the trade the accounting books are created bringing the record of all the movements that will be transferred to paper (Sommerville, 2005). With the arrival of the industrial revolution, new methods to keep data and speed up time (typewriters) arise, it is here where more caution is taken regarding the importance of assets and their benefits, also the first financial statements begin to appear with the perfection of the double entry (axiom of accounting) (Lavarda et al., 2009; Roselló Gallardo, 2017). In the 20th century, specifically between the 60's and 80's, a greater flow of information begins to be handled more quickly and will influence the decision-making of organizations. This is why computers were created to facilitate the work of people, since so much information was needed by so many users, and the automation of the old accounting systems began. In other words, what was written on paper is now all in a computer, which produced reports, graphs, financial statements, ratios, and other information to provide a broader vision of the entity's operation (Liberona and Ruiz, 2013).

Today, with globalization, everything is instantaneous, so information is in real time, it is fast and you can get everything you need with a single click. Due to the amount of information and magnitude of the organizations, new technologies are being created to meet the needs required by each entity, thus creating the Electronic Commerce where intangible assets are imposed over tangible ones (Garrett and Skevington, 1999; Tang et al., 2006). This leads to the obligation for companies to adapt to new ICTs because if they do not do so, they may become obsolete and disappear from the market. Organizational structures have also changed, since communication between people has been evolving and this creates a change in the hierarchical pyramid from vertical to horizontal, causing a flow of information and the relationship between individuals (Abrego Almazán et al., 2017; Oliva et al., 2018; Riascos-Erazo and Arias-Cardona, n.d.).

\subsection{Software Audit}

The audit is a process in which evidence is obtained and evaluated in an objective manner related to the information reported on economic activities and other related areas, in order to determine and compare what is reported with what gave rise to it, in order to produce a report that accounts for everything reported as reliable and faithfully representing the situation being audited (González and Ruiz, 2018; López et al., 2011).

It is the review and diagnosis of procedures, controls and software systems that give the certainty of their optimal use, that they are effective and that they comply with the security foreseen by the management of an entity since it is the same one in charge of providing information to the system which is an influential factor when making decisions (Isolano, 2003; Villar, 2020). In addition to the already mentioned, the systems audit also looks for to safeguard the entrance data until the transformation in information of these, providing the controls that are necessary to carry out a good performance and the maximum security of the organization, this is known as protection of information assets (Nahabetián Brunet, 2015).

\subsection{Intangible Assets: Software}

Intangible assets are items controlled by an entity and that generate benefits to the entity but are identifiable, not physical or monetary [21]. Among these are trademarks, copyrights, licenses of use, advertising, and employee knowledge and skills, among others. In conclusion, it is everything that is not tangible and that gives value to the organization.

Among the intangible assets is the software, which corresponds to computer programs that are fed by the information provided by users who occupy this system. They can be for a specific client or for general 


\section{International Journal of Economics, Business and Accounting Research (IJEBAR) \\ Peer Reviewed - International Journal \\ Vol-4, Issue-2, 2020 (IJEBAR) \\ E-ISSN: 2614-1280 P-ISSN 2622-4771 \\ https://jurnal.stie-aas.ac.id/index.php/IJEBAR}

use by those who require it. Good software provides the beneficiary with sustainability, reliability and affordability [22], [23].

\section{Software engineering process}

\subsection{General characteristics}

The input data of a system is subjected to several logical or algorithmic processes that together create the information which is available to the user. One of the main risks of the systems is the security of its data, which cannot be effective unless the software design describes procedures and controls that ensure veracity and consistency in the entered data (Alhazmi et al., 2005; Rehman and Mustafa, 2009; Surakhi et al., 2017). From the auditor's point of view, the role played by the auditor is crucial within the organization, both in the software development process and in the planning and structure, in addition to ensuring that applications are built correctly and appropriately as agreed by the specialists, the project manager and the software engineering process (Fowler and Rifkin, 1990; Humphrey, 1988; Ross et al., 1975). This ensures that factors such as control, security and audits of individual systems are considered from the outset. For this requirement to be met, IT specialists are needed as they can intuit or detect the issue of data security and thus be able to integrate it into the software development process (Manwadkar, 2018).

Among the characteristics of this process, there are also participants in everything that involves the audit of the software project that they are (Chou et al., 1998; Dodd and Habli, 2012; Walker, 1998):

1. Project Manager: This is the person in charge of the project who is responsible for planning the timing, specifications, risks that may arise before and after the process, and is responsible for communication with customers, among others.

2. Project Leader: Unlike the project manager, this one is in charge of all the elements that make up a good project, the before and after, that is, he is concerned with the needs already specified by those who will use it, the development and its monitoring.

3. Analyst: This person is the one who takes care of the plans, supervises the information systems, is the one who shapes what the user who will occupy the system needs, as long as the requirements are so well specified that the analyst can generate a faithful image to them.

4. Programmer: As for the programmer, this must be someone who knows what he is doing since he is the one who makes everything already mentioned come true, such as the specifications, the needs, the logistics and everything related to the way the software is developed. He is tool-oriented, that is, he is the one who cares that the software can be used in an efficient and effective way and that it can be easily and clearly handled.

5. Testing: It is the one that controls the system, makes the software tests, it worries that everything is working correctly and that all the needs of the organization and/or user that requires it are being fulfilled. It is not so valued, but it is very important since it is the one who cares that the system is coupled in the best possible way to the entity that obtains it.

After all the above is where the participant comes in who is not more important than the others, but it is the person of our interest to investigate and know what his role will be within this process, this is The Auditor. As mentioned at the beginning of this section, his importance is of such magnitude that he functions as a quality manager within the acquisition and operation of the software because he is the one who cares that everything is well stipulated in order to guarantee the success of the incorporation of this system. The auditor also functions as an advisor to the entity that hired him, since it is his job to point out the risks that may be incurred, to let the user know what is in his best interest, according to the characteristics of the person requesting a software and also according to the market indexes, so that the risk of being deceived by the different information system service providers is minimized (Ahmi et al., 2014; Sacha, n.d.). As can be seen in Figure 1, the auditor does not have a direct or subordinate 


\section{International Journal of Economics, Business and Accounting Research (IJEBAR) \\ Peer Reviewed - International Journal \\ Vol-4, Issue-2, 2020 (IJEBAR) \\ E-ISSN: 2614-1280 P-ISSN 2622-4771 \\ https://jurnal.stie-aas.ac.id/index.php/IJEBAR}

relationship with any member of the software engineering team, this is to ensure its independence from the process analysis.

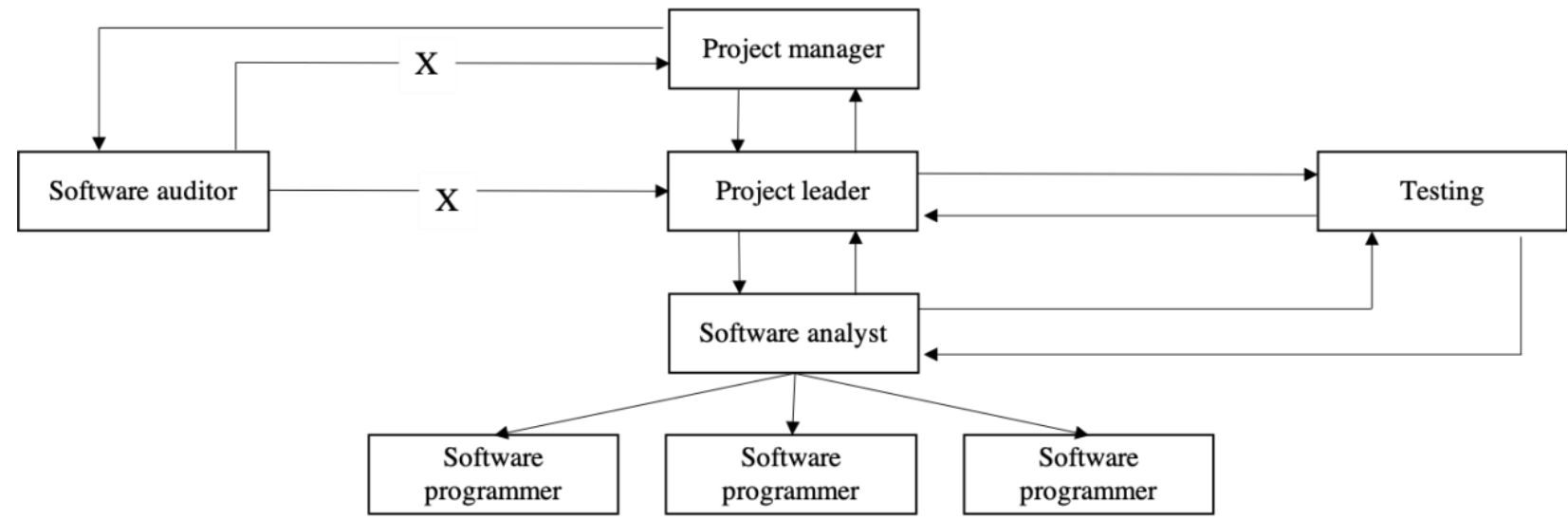

Figure 1. Relationships in the work team and the software auditor

\subsection{Stages}

The acquisition of a software is not a simple matter, it must be taken into account that this is often a quite extensive process. When we speak of software acquisition we refer to two options, the acquisition of a program already made or under development and adapt it to the company, or create a software from scratch, depending on the needs and requirements of the company (Calvo-Manzano et al., 2010, p.; Gloria Piedad et al., 2014). The organization when determining that it wants a software in its company must choose between these two options taking into account certain factors, such as for example that when buying a software already made or under development, the needs will be covered generically, there will be the possibility that the software does not meet all the requirements of the company, you must also manage the purchase and installation of this software; However, if it is decided to create a software from scratch, it will be created under all the requirements and needs that the organization poses, there will be a greater possibility that the acquired software will meet all the needs of the company, but it must also be considered that developing a software implies managing material and human resources, time, money, among other factors that may affect the creation of the software (Adams et al. , 2004; Farbey and Finkelstein, 2001; Hayen, 2004). The process of acquiring a software either to buy or to create can be divided in some stages that we will point out next:

1. Project review: At this stage everything related to the acquisition of the software must be planned, it must be verified that each of the requirements are well specified, as well as taking into account the allocation of resources when using materials, human resources and money, the time it will take, who will be in charge of the software project, the design, etc.

2. Acquisition process: Once we have seen all that is necessary for the acquisition of the software, we will start with the acquisition process, which as we said before can be done by buying a ready-made one, so a good market study will have to be done in order to choose the one that best suits the needs of the company, or one can be developed from scratch, within the same company, or by entrusting the software development to companies in charge of this, so a good search will also have to be done in order to find the best organization and entrust it with the development of the new software.

3. Follow up: When the new software has been bought or developed, it must be followed up to see if it really serves and fulfills the functions for which it was acquired. It is worth mentioning that the follow up must be done from the beginning; if the software was developed from scratch, this follow up must be done from the moment it was designed. 


\section{International Journal of Economics, Business and Accounting Research (IJEBAR) Peer Reviewed - International Journal \\ Vol-4, Issue-2, 2020 (IJEBAR) \\ E-ISSN: 2614-1280 P-ISSN 2622-4771}

https://jurnal.stie-aas.ac.id/index.php/IJEBAR

These stages must be controlled or managed at all times, therefore, this is when we talk about the software audit term that was defined above. Figure 2 shows how the auditor is present in each of the macro-stages referred to above.

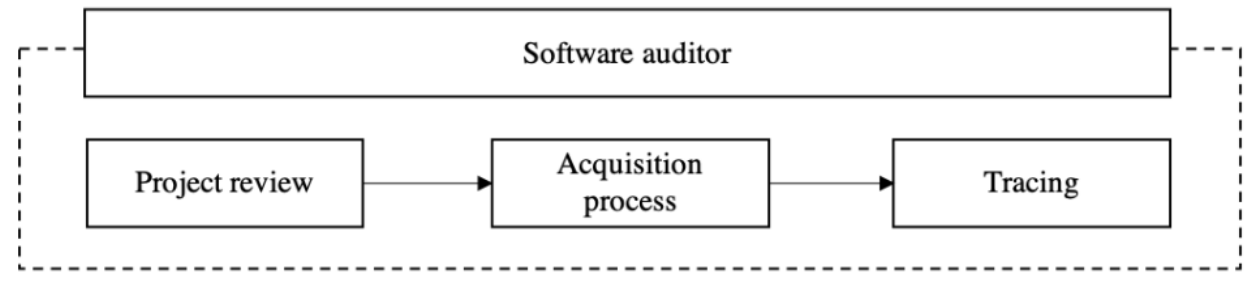

Figure 2. Auditor's presence in procurement stages

Lately, software auditing has become very important within organizations, since it often depends on it that the new acquisition or the software that was already within the company works as planned and fulfills all its functions in the best way (Valencia Duque, 2015). The software audit comprises the review, control and analysis of all the software that exists within the company. This process can also be classified within the following stages:

1. Requirements Review: The requirements are those characteristics that the software must have, to fulfill the necessities of the company, it must be reviewed that they are well indicated and that they are raised based on the true necessities of the company.

2. Review of specifications: It details each one of the functions and the behavior of the software, up to the most minimum characteristics

3. Review of selection processes: This process refers to the moment in which you must choose who will be in charge of the development of our software or if you buy a ready-made software which will be the supplier of this one, you must choose the best of the options according to our requirements and specifications.

4. Revision of customization processes: refers to the fact that the software will be created for the company and according to its needs, the company's characteristic colors and brands can also be included in the customization.

5. Revision of tests and installation: when starting a new software in the company it must have a test process, it is that the new software will be installed and used to verify if it really fulfills all the characteristics, functions and needs raised by the company.

6. Delivery review: After the tests, when it is seen that the product complies with all of the above, the delivery of the product will be made, which must be in accordance with the agreements between the two organizations.

\section{Legal regulations}

As it is generally known, in Chile today technology is used in all areas, this means that it can be good or bad depending on how it is used in this case, because just as technology is an important advance so as not to be left behind in terms of development, it is also being used incorrectly and in favor of some people, for example to deceive people and obtain benefits from that (Bănărescu, 2015). That is why it is worrying that in the country there was no legislation with issues like this, more contingent and updated since there was only the law 19,223 that originated in 1993 focused on situations such as espionage and sabotage. After 23 years the legislation was updated, that is, in 2017 Chile recently renewed its law against cybercrime through the Budapest Convention (Gómez, 2010) which was published at the end of August 2017, so it has only been in force for a couple of months, this agreement includes eight new crimes that will be mentioned below: Visual and sound capture of information without consent; dissemination of such 


\section{International Journal of Economics, Business and Accounting Research (IJEBAR) Peer Reviewed - International Journal Vol-4, Issue-2, 2020 (IJEBAR) E-ISSN: 2614-1280 P-ISSN 2622-4771 \\ https://jurnal.stie-aas.ac.id/index.php/IJEBAR}

material; production of programs or devices to commit crimes; dissemination of information from a computer system; manipulation of confidential keys and encrypted data from a bank card; use of programs or devices to violate data integrity; alteration or damage to computer systems and alteration of data to access a computer system.

Before the Budapest project was carried out, the IT law was without a legal framework to regulate it, so in many cases those affected were left unprotected. From this it can be inferred that Chilean legislation does not contemplate in the least all that can happen through information technology, as an example we can put the La Polar Company (Fernández et al, 2015) which carried out a computer fraud by altering its financial information and carrying out operations parallel to the normal operations of the company (unilateral repurchases) where customers from different places in both the north and south of the country were affected. This is to make it clear that the magnitude of a fraud like this directly affects people, so that in Chile no legal forms have been created to protect the entire population and the whole issue itself (Vergara Rojas and Vergara Rojas, 2017).

In a more general or international scope we can find an organization called UN (United Nations Organization) which determines three types of computer crimes: deception committed through the manipulation of computers, adulteration of input data and damage or transformation of programs and / or computer data (Arocena, 2012; Mayer Lux and Mayer Lux, 2018). On the other hand, the OECD (Organization for Economic Cooperation and Development) has also been involved in this issue since 1983, when it began a kind of study and research on the possibility of applying a legal framework to information systems at the international level in order to prevent their misuse. In 1992 the International Association of Penal Law adopted new recommendations in which it indicated that if the Penal Law alone did not manage to cover all the types of crimes that exist, an update should be made with respect to this definition since a normal crime is very different from a computer crime, although both have in their essence to cause an evil to a third party and go against what is legally established (Contreras Clunes, 2003). Finally, the OECD published a study on computer-related crime in which an analysis was made of the legality of the new regulations in force, thus also defining what computer-related crime is. In addition to this, it also created a set of rules so that different countries could be guided by it in order to protect the information as much as possible, since today this technology and these new methodologies to carry out certain actions, has become a tool that greatly facilitates the misappropriation of information as it could be said that it is an effective method that often leaves no traces (Cerda Silva, 2011; Quintanilla and Isabel, 2013; Salguero and Javier, 2016).

Therefore, it should be noted that it is not technology that is bad in society but ambitious people who want to power in an easy way and technology gives them the necessary tools to achieve it. The reality of different countries shows that at the Latin American level there is a deficiency. For example, Spain is one of the countries that has been most affected by the misuse of computer systems, which is why with its Organic Law on the Protection of Personal Data (enacted in 1999) it seeks to punish people who commit a crime such as espionage, the violation of private information, introducing viruses, etc. With fines and imprisonment being sensitive at the time of issuing a sentence being guided by the size of the damage that has been created, that is, it will depend on the degree to which the deceived person was taken (Cerda Silva, 2006). The United States is one of the most important countries in the world and it is not surprising that this is where there is the most history in terms of information technology. It was in 1976 when this issue began to be taken into account because before this there were no standards so attacks on information systems were more common. Thanks to the FBI, a kind of course was given to the agents so that they were aware of the computer issue and the Government Affairs Committee of the House presented reports that marked the origin of the Federal Law of Systems Protection in 1985. A year later, the Computer Fraud and Abuse Act was born and was replaced in 1994 by the Federal Computer Abuse Act, These legal figures mentioned above refer in general to companies that have to do with the state, to the damage that can be created to a system with viruses or in other ways, use of other people's information, among others. The most important body regarding computer fraud issues is the Federal Computer Investigation 


\section{International Journal of Economics, Business and Accounting Research (IJEBAR) Peer Reviewed - International Journal \\ Vol-4, Issue-2, 2020 (IJEBAR) \\ E-ISSN: 2614-1280 P-ISSN 2622-4771}

https://jurnal.stie-aas.ac.id/index.php/IJEBAR

Committee known as FCIC (Edwards, 2020). Finally, Holland was full of computer criminals until 1993 when the Computer Crimes Act was created. This law has specific items about hacking and phreaking, the latter being understood as a type of hacking but by telephone, since it has the combination of "phone" and "freak". With respect to the punishment that people have who act against a computer system varies depending on its nature and this can be from 1 year to 15 years, this final mentioned that is the longest will apply if the crime caused the death of a third party (Claver, 2018).

In the legal field of the auditor this is controlled by the Association of Accountants Guild since it is this entity that makes known the standards that guide the auditors through its National Council that empowers them within the rules imposed by the Association of Accountants we can find those of witnessing, quality, ethics, among others. Also with regard to the legislation of the auditors we find the International Financial Reporting Standards and International Accounting Standards, IFRS and IAS respectively according to its acronym, on the other hand we also have the Superintendence of Securities and Insurance (SVS) who is also empowered to publish standards and that has the same importance as the International Standards since it is concerned with the Securities Market and its transactions.

Many milestones are known from the types of crimes mentioned above where the auditor is involved who is responsible for realizing the irregularities that are created within an organization and who is complying with the legal regulations of each country, On the other hand we have the natural persons that although the auditor cannot take charge of everything that such person does, he can get involved as soon as he has supervised the organizations that have to do with each crime, that is to say, in the case of phreaking the auditor could be involved in seeing the systems of the telephone services where he ensures that they are complying with the legality, transparency and security of the data in order to detect in time what is happening. Based on the above, it is very important that organizations are careful with the contracts they have with other entities that provide them with software creation services, since that is where the legal framework that will regulate them is stipulated and made clear, in order to avoid misinterpretations and to stay within what has been agreed upon. The auditor has a great responsibility since he is the one who must verify that everything is being complied with in a good way, that there are no errors, that the specifications of whoever needs a software are being well interpreted so that there is a minimum percentage of error between what is wanted and what is available and always within the legal framework that each country indicates.

The software projects are continuously developed, are governed and managed under certain laws and rules that make this project operate under the law and this in a constant good performance. The most recurrent standards are:

1. ISO 9001 standards: the organizations dedicated to the development, supply and maintenance of software. Its objective is that the software project is carried out with a quality management, guaranteeing the correct application of the standard, this help to deliver a good service must be with the requirements within the stages of planning and development of this (Auer et al., 1996; Avison et al., 1994; Paulk, 1995; Stålhane and Hanssen, 2008).

2. Spice: An international standard that is continuously being developed for software processes, this standard contains stages which are preparation, data collection, compilation and analysis (Dorling, 1993; Madec et al., 2017; Tupe et al., 2009).

3. CMM Standard (Capability Maturity Model): It is a software quality model that qualifies the level of maturity of the company, these levels are to know the maturity of the processes to produce software has five levels: initial, repeatable, defined, managed, optimized (Jalote, 1999; Niazi, 2006).

Software projects must be licensed in order for the software to be legal. This is the procedure of granting another person or company the right to use the software for commercial, industrial purposes, etc. The types of licensing among the most prominent are (Arriola Navarrete et al., 2011): 


\section{International Journal of Economics, Business and Accounting Research (IJEBAR) Peer Reviewed - International Journal Vol-4, Issue-2, 2020 (IJEBAR) \\ E-ISSN: 2614-1280 P-ISSN 2622-4771 \\ https://jurnal.stie-aas.ac.id/index.php/IJEBAR}

1. Software with Copyletf: This is software that does not allow it to be added or modified when it is redistributed.

2. Freeware: Allows free programs to be used for an unlimited time with restrictions that cannot be modified in a commercial way.

3. Opensuorce: Allows the user to modify or alter the data in the software file.

4. Shareware: Software that must be paid for on an ongoing basis.

5. Commercial software: Used for the purchase and sale of the company that acquires it, this software does not allow modifications.

6. Custom software: Software that meets the requirements of the client

7. Open Source: Freely distributed and developed software can be modified.

The advantages of software licenses are that they are used legally and the rights of use are protected, they present guarantees for the correct functioning of the software and these depend on the size of the software and the duration of the guarantee, so the license must be valid. The illegal use of software is growing at high levels in all countries and this causes sanctions at national level Chilean Law 17,336 establishes a fine of 5 to 50 Unidades Tributarias de Fomento (UTM) and at international level the country Colombia has prison sanctions of two to five years and a fine of high figures, in the case of Spain the Spanish code provides for prison sentences of up to four years and fines of 288,000 Euros and large compensations for damage to information data and national infraction and closure of companies.

\section{Current status}

In recent years Chile has had a growth in terms of information technology as they are increasingly necessary for the daily operations of organizations and that is why they have been increasing spending on software projects that cover their needs, for example in 2009 the state had an expenditure of U.S. \$ 58.3 million which are intended to create systems for public entities and in $2013 \mathrm{had}$ an increase to U.S. \$ 69.1 million which is logical because it is increasingly essential to this tool because companies depend on computer resources to operate.

It is known that when people invest or buy a product or service, they expect to occupy the acquired good for some future use or benefit, in the case of software the situation becomes a little more complex because it is the largest investment that the company makes and the percentages of use of software are inversely proportional to what one expects, since about $5 \%$ use the acquired software, $20 \%$ use it and then generally abandon it because of the resistance to change that people adopt, $47 \%$ of clients receive the software but do not occupy it, a figure that marks an impact in terms of incompatibility or lack of training for staff due to the overloaded hours that exist on the part of project managers or simply due to lack of resources and allocation of specialized personnel, and finally $29 \%$ are in the paid but not delivered (Guerrero and Londoño, 2016; Lara et al. , 2001; Martelo et al., 2017).

As time goes by, the economic impact generated by software throughout the world brings with it repercussions that can be beneficial for countries with advanced technological development, such as European Union countries. The dependence on software in the 21 st century generates organizational changes that bring with it an increase in jobs, creates opportunities for different types of professionals, especially in the area of information technology, program designers, administrative and financial personnel, allowing them to work more effectively, efficiently and creatively. Software is how organizations are everywhere, and therefore its development has repercussions in different industries, whether in education, health services, livestock, food, etc. (Antonella, 2016; Brosius et al., 2019; Fujita and Papadopoulos, 2016; Ghosh, 2007). Companies are increasingly digitizing their information, and as a result, cybersecurity has become very important in recent times. This is why the costs and resources used in system security must be included in the budget, according to the size of the organization, and the more digitized the platforms and structures used, the greater the security and resources needed to protect them 


\section{International Journal of Economics, Business and Accounting Research (IJEBAR) Peer Reviewed - International Journal \\ Vol-4, Issue-2, 2020 (IJEBAR) \\ E-ISSN: 2614-1280 P-ISSN 2622-4771 \\ https://jurnal.stie-aas.ac.id/index.php/IJEBAR}

(Cabaj et al., 2018; Garae and Ko, 2017; Jang-Jaccard and Nepal, 2014; Kruse et al., 2017; Ronquillo et al., 2018).

Organizations are aware of the real cost that a data security or fraud problem could bring in terms of reputation and financial consequences. In Europe, the most common and costly security problems are viruses and malicious software that cause productivity losses and inappropriate use of IT resources by employees. Software development has become the current and future work that projects the continuity and evolution of companies, which is why the European Union focuses its business objectives on the contribution and design of software generating direct jobs (staff directly linked to the software) and indirect jobs (staff involved in the organization through the software project). The Economist Intelligence Unit in the year 2014 made an analysis of how the economy has improved with the systems, measuring the percentage of increase in jobs, salaries and GDP in the European Union, the data expressed shows an increase in total employment of 5.3\% over the previous year (2013) generating 11.6 million jobs, also it is extracted that the salaries generated by the software industry are $34 \%$ higher than the average of the other sectors and $80 \%$ higher than the service sector, the average salary of the software industry is 333 which in Chilean pesos translates to approximately $\$ 33,000,000$ (Al-Qudah et al, 2015; Jorgensen and Shepperd, 2007; Stamelos et al., 2003).

\section{Proposed business process}

In every organization that is currently in force, information systems are present, since due to their processes they must be automated in order to be updated and not become obsolete in the market. This is where the need to use tools that facilitate this task arises, which is why many companies have chosen to implement ERP (Enterprise Resource Planning) systems according to the English acronym, but in Spanish it means Enterprise Resource Planning) which basically takes care of planning in an efficient way all the resources and processes that the entity has in order to be able to increase its productivity, profitability and security (Klaus et al. , 2000; Matende and Ogao, 2013). Obviously, investing in these types of systems, which are mainly aimed at large companies, means a great expense for the organization because, as it increases in size, so do its processes, so the systems are also larger and with a high level of complexity.

A business process is a set of tasks that are related to each other to achieve a particular purpose, it is important that in a company this process is well defined, adapted and synchronized with other processes, so that in this way they can achieve their organizational objectives efficiently and effectively leading the company to position itself over its competition and win market (Recker, 2012; Respício and Domingos, 2015). Thus, the incorporation of software to companies and their business processes positively affects many areas, such as reducing operating costs, reducing time spent on these processes, automation, or as has been pointed out throughout this report, reducing errors and resources (Oliva et al., 2018).

In this aspect, there are two softwares that we consider very helpful for the management of the company and its business processes, these are the enterprise management softwares or also known as ERP and the business process management softwares also known as BPM. Business Process Management (BPM) software helps companies to define, organize and model each of the tasks or activities that make up their business processes, thus reducing costs and increasing profits. The software of management of companies or ERP for his initials in English "Enterprise Resource Planning" this program offers solutions to countable and administrative problems in the organization, helps to automate and to define processes, to share and to store information in real time, the functions that this program can supply can be, accounting, human resources, inventory, invoicing, between others. 
International Journal of Economics, Business and Accounting Research (IJEBAR)

Peer Reviewed - International Journal

Vol-4, Issue-2, 2020 (IJEBAR)

E-ISSN: 2614-1280 P-ISSN 2622-4771

https://jurnal.stie-aas.ac.id/index.php/IJEBAR

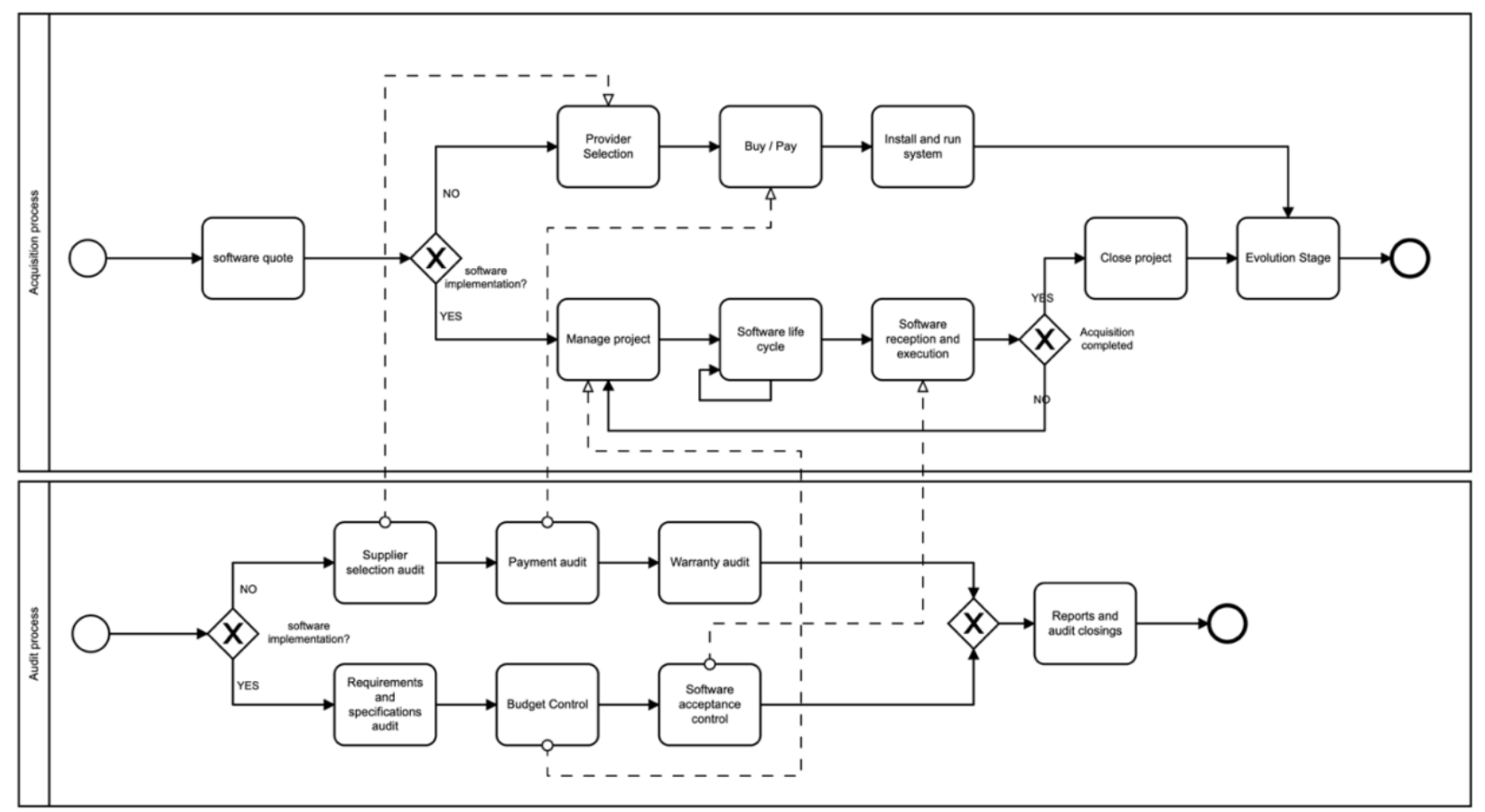

Figure 3. proposed process metamodel for the audit.

In Figure 3 you can see a metamodel with the processes defined in conjunction with the macro processes that make up the acquisition of information systems and the relationship that the auditor takes with each of them when controlling and implementing the various methodological resources that have been defined in the company. After all the above mentioned we can include the work of the auditor that in this case would serve much as an adviser of the implementation of this type of systems because it is his work to be aware of the offer of these systems and thus be able to make a study that allows the entity to know which way to choose. To be able to give a good advising it is needed of certain stages by which the auditor should happen, the first part of the process of audit in the implementation of a software is the meeting that is had with the client, is of extreme importance since it is a diagnosis to know the processes that are wanted to include/to control and what is expected to obtain of this one, is for that reason it is due to detail with which means it is wanted to manage, in addition to the budget.

In addition, this process is recommended to support it in some ERP, in this case, the proposal is shown in Figure 4, for which OBUMA ERP is used in areas of functionality of Invoice and electronic ballot, Inventory, Accounting, to the enclosure of the Balance up to column "balances".
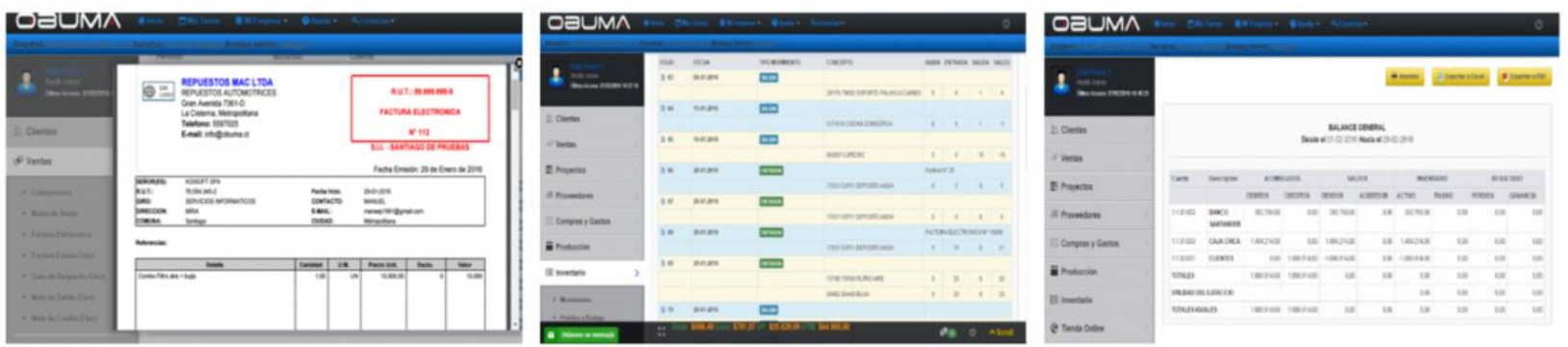

Figure 4. Proposed ERP at work. 


\section{International Journal of Economics, Business and Accounting Research (IJEBAR) Peer Reviewed - International Journal Vol-4, Issue-2, 2020 (IJEBAR) E-ISSN: 2614-1280 P-ISSN 2622-4771 \\ https://jurnal.stie-aas.ac.id/index.php/IJEBAR}

The organization must be clear about the processes it wants to standardize to make management easier and faster, this lies in eliminating the processes that do not add value or hinder the processing of the software. Once the processes to be standardized are clear, the most appropriate ERP for the organization must be chosen. When implementing it, the risk is resistance to change, so it is good to inform people about the benefits of this new tool in terms of their work. Then you have a test phase where it is necessary that the auditor is present to check that there are no errors in the operations and thus correct it as soon as possible, constantly making corrections so that the software continues to meet the needs.

In addition, there must be a series of facilitating tools for the auditor. A number of audit support systems are envisaged for this proposal:

1. EZSBenford: Oriented to establish the correlation of figures through repetitions in a document in order to search for frequencies and compare data (expected $\mathrm{v} / \mathrm{s}$ real). This system receives a file which is made a type of analysis as the user wants, to get a greater field in the search according to the needs or priorities of each auditor, this is very helpful because you can identify more quickly if there is something abnormal within the data and evaluate and compare them too. From a financial point of view it is very helpful since it manages to identify errors or irregularities that are difficult to notice in this area.

2. WINAUDIT: It is a computer program that quickly shows all the information regarding installed programs, a kind of inventory of the organization that in a few minutes delivers a list with everything that the computer has incorporated. From an auditor's point of view, this process is useful when identifying what programs are used within the organization and what they are used for. It identifies types of personal software that employees have, what models of computers are used and for what services they are prepared, and recognizes whether or not the software is licensed, which helps control the legality of these.

3. RUSecure(TM): Protects the information and its systems, also identifies actions that put the entity's data at risk which helps to evaluate possible irregularities that may occur. It helps to emphasize the importance of the information, since the loss or theft of it generates such a great impact that many times the risk to which the organizations are submitted has repercussion in their processes and therefore in their results. It is of great help to the auditor when making recommendations on information management.

4. NG_SCORING: It finds the degree of similarity between two or more sequences of data, it is similar to the system already mentioned EZSBenford. This tool works by asking the system questions that check security settings and controls as well as verifying how repetitive certain activities are helping the auditor to realize and advise on what might be causing a failure in the functioning of the entity by doing tasks that may not be necessary.

5. RAT_2.2.WIN32-NATIVE-INSTALLER: Program that allows us to download and analyze the devices, looking for security flaws in their configuration. It is key to determine the security that the devices have, at audit level it generates benefits at the moment of making the reports identifying errors, in addition the software delivers a document to solve the configuration problems being very useful for the auditor at the moment of being able to exercise his work and give the corresponding recommendations to the organization.

\section{Impact and Results}

Nowadays the creation of new information technologies has changed forever the way of working and handling information, maximizing productivity levels and allowing an easier and more efficient work. It has a great amount of benefits such as the improvement of teamwork, thus reducing the time spent on solving problems. The information is instantaneous, this means that several people can be working on the basis of a document and be changing it in real time where they are, it is not necessary to be in the company to enter the platforms just an internet connection, this also allows an exchange of information 


\section{International Journal of Economics, Business and Accounting Research (IJEBAR) Peer Reviewed - International Journal Vol-4, Issue-2, 2020 (IJEBAR) E-ISSN: 2614-1280 P-ISSN 2622-4771 \\ https://jurnal.stie-aas.ac.id/index.php/IJEBAR}

between different computer services. Annual updates are received which leads to a continuous improvement of the system, making the same processes in different ways.

In Chile the information systems have a high percentage of use, since it is one of the Latin American countries where the internet is most used, the Digital Country Index 2017 proposed in a report that by $202095 \%$ of Chileans will be totally internalized in the world of digitalization (Uzelac, 2008). This shows us that the impact it has on people and especially on Chileans is so high that it is impossible to go backwards and the only thing left to do is to advance as the technological world demands, so surely in a couple of years there will be more and new ways of interacting with technology.

In terms of accounting, the impact that technology and software produce in this area first, and which is the most notorious, is that the new technology came to replace the old practices that were like writing by hand, passing everything to a physical book, etc. So what happens now with accounting is that if people do not update themselves and resist the change they will gradually become obsolete since there are programs that do most of the work of accounting and this causes a demand by those who are in the accounting area since they must be molded to the new era and new technologies. On the one hand, this can be bad for people as long as they do not adapt, but on the other hand, it has a positive impact because accounting processes have been speeding up, thus creating a better interaction between the company, its clients and the very employees working in the organizations.

Regarding the role of the auditor and the way in which he must act due to this constant change, we can say that auditors depend on their skills to detect threats and strengths of different environments, each organization has a specific audit so there must be auditors for each type of company. The meeting with the client is of great importance since from it we extract the information that the entity provides them and thus to be able to audit it in a correct way, so that in the process they verify that it is fulfilling the real needs of the organization to advise the entity in topics like its policies, what type of software they should implement, what processes they should improve or change, if there are new methodologies that make it more effective, among others, so that they can remain in force and have comparative advantages over others and remain competitive in the environment in which they operate.

In relation to the impact that has been seen about the information technologies in the companies it can be pointed out that in the big companies it is where it has been seen more inclusion of this resource. This can somehow be reflected in a study carried out with the "Ministry of Economy, Development and Tourism" where it indicates that when carrying out a survey to more than 302,000 companies, among them large, medium, small and micro enterprises, and collecting data on whether they used information technologies such as desktop computers, servers, laptops, tablets or smartphones in their companies, the result was that $99.8 \%$ of large companies have at least one of these technologies, while $81.2 \%$ of micro enterprises had at least one of the elements mentioned above, having these technological elements in addition to the Internet also gave rise to companies wishing to acquire more complex systems to take advantage of these and thus be able to streamline processes within the company, reduce time and errors, among other things, this can be achieved through the use of software (Solimano, 2012).

If we analyze these results but from an accounting, financial point of view, the acquisition of a software can not be taken lightly because as well as advantages to the company such as cost reduction, streamlining processes, reducing errors, security and rapid access to information, if a bad decision is taken can adversely affect within the processes and activities of the company which would end up adversely affecting the accounting of the company, the software if it is badly used or directly not used can generate great losses within the company, since the acquisition of a software implies an investment of much money, the ideal is to use it to the maximum to generate benefits, like those indicated before which would help the company to work in a better way and to increase the yield of this one and thus the great investment is justified. When acquiring the software, the price is one of the areas to consider, although it is not the most important, for some companies it can become the reason to accept or to discard a software proposal, since when you want to acquire a software program you must have a number in mind and try 


\section{International Journal of Economics, Business and Accounting Research (IJEBAR) Peer Reviewed - International Journal \\ Vol-4, Issue-2, 2020 (IJEBAR) \\ E-ISSN: 2614-1280 P-ISSN 2622-4771 \\ https://jurnal.stie-aas.ac.id/index.php/IJEBAR}

that this one does not surpass that number in order not to disburse more money of the planned one and later to generate enormous losses within the company.

Therefore, for the acquisition of software to be well received, there must be a detailed planning of this, that is to say, taking into account the requirements of the software, the needs that it must satisfy, who will be in charge of developing it, how and where it will be executed, the total price of the software, among many other and varied areas of importance in the organization. In this planning process, the auditor will be able to fulfill some important functions, which can help to acquire the best software for the company. It is important to emphasize that the auditor has as main function to inform, since his role is not focused in intervening in the development of the software, but, to warn or to give the necessary information to avoid problems. Some of the functions that the auditor can develop in a software acquisition process can be:

1. To control or monitor the resources allocated for the acquisition or development of software, the auditor should be concerned that the money used is optimal, that excessive resources are not used.

2. Another role that the auditor can play in the software development process is to provide information needed for the development, but only in some cases, for example, if the software will be for the area of finance or accounting, which is one of the areas most covered by software applications, the auditor may be able to provide some requirements that need to be covered by the software.

3. The auditor may participate in the software selection process by providing an opinion on all possible software to be acquired.

4. He should report any failure or suspicion of it to the company he is working for.

\section{Conclusions}

If we think about the future, after the great technological advances until today, it is easy to project ourselves in an innate way; we know that technology will continue to advance by leaps and bounds, software will continue to evolve and technology will replace man, however, it is in man the key to the efficient construction and operation of software, that is why human capital will always be necessary if we refer to information technologies.

As it has been exposed throughout the report, the Auditor during the whole process must have control of what is being developed with respect to the software; and this must continue in the future, since the environment, being in constant change, also changes the needs of the company, and these will therefore need new or modified software. Therefore, the Auditor is expected to be always flexible to these changes and be able to continue controlling and informing the company of any existing errors.

It is also expected that in the future, at a national and international level, the number of software acquisitions will continue to increase, supported by the technological level of the country.

Finally, we can say that software is an important part for all companies, since it helps them to position themselves in the market, increase the efficiency and effectiveness of their business processes and in general helps the company to reduce costs and increase profits, which is one of the most important points for large companies, therefore in our opinion, spending on this subject is more than justified, and as mentioned above, it is expected to increase.

\subsection{Final discussion}

We must appreciate the importance of tics in our daily lives, the need to continue to update and be at the forefront of current issues such as technology. For the accountants in formation, it is key to be assertive in their future work, as far as detecting errors that can arise in the audit of projects of software since these are one of the most important assets in the organization since it is the one that contains relevant information for the decision making and is the tool that takes care of for almost all process of business. It is also important not to distort this information or its use as it could cause damage to third parties, which is why we must act in an honest and transparent way when it comes to information systems, they must 


\section{International Journal of Economics, Business and Accounting Research (IJEBAR) Peer Reviewed - International Journal Vol-4, Issue-2, 2020 (IJEBAR) \\ E-ISSN: 2614-1280 P-ISSN 2622-4771 \\ https://jurnal.stie-aas.ac.id/index.php/IJEBAR}

also ensure that they are complying with everything required by the company at the time of acquisition of a software also with what indicates the legal framework of the issue addressed. As mentioned in the research, in a couple of years in Chile practically the entire population will be aware of the technology so it is our duty to adapt to new methodologies that will emerge to remain current and competitive professionals in the market.

\subsection{Future work}

It is impossible to determine exactly what will happen with the software in the future since we live in a world of uncertainty, but it is expected that the systems will expand to the level of bringing computer programming to schools, as is the case of the United Kingdom that took this initiative in search of generating good results in young people at work, this idea should take strength within countries as they evolve, Another example is that of the United States where a television program was implemented to introduce the population to the language of information technology. It is hoped that the other countries will take into consideration and begin to implement more programs with this theme which will finally be the work of the future which will allow the economic and intellectual growth of each country, hoping that programming will be a universal language within the next few years.

The user of the future is much more demanding since he will know more, will be able to establish differences and will be more informed in relation to the technology, forcing the systems to continue innovating within his area and exploiting the TIC'S of overmuch, to be able to satisfy the needs that the clients require. The cybernetic security is already a contingent subject and in the future it is expected to be able to personalize the applications, looking for all the alternatives to cover this risk since the hacking or bad use of data can be an ambivalent weapon that generates great monetary losses.

We will have more knowledge about software projects and some programming therefore is expected to find the most demanding users of the century, the alternatives will multiply, generating a competition at a cyber level quite broad, which may allow a growth computer that will generate new challenges in this area.

The growing development will cause a great impact in the way of working, taking force the creation of robots, machines which will be in charge of replacing people and automating more than half of the processes that are developed today. The industries that are subject to this change with the greatest loss of jobs are retail, manufacturing and public sector administration where routines are generally very marked, allowing the machine to do the job more efficiently than people. If this were to happen in Chile, more than $40 \%$ of the population would lose their jobs and we would enter a new historical process in which the human is replaced by a robot. We can only speculate or estimate about this since we live in an uncertain world and the only constant thing is change (Birk and Pfahl, 2002; Huh, 2001; Masaeli et al., 2019; Zelkowitz, 1978).

\section{References}

Abrego Almazán, D., Sánchez Tovar, Y., Medina Quintero, J.M., 2017. Influencia de los sistemas de información en los resultados organizacionales. Contaduría y Administración 62, 303-320. https://doi.org/10.1016/j.cya.2016.07.005

Adams, R., Eslinger, S., Owens, K., Rich, M., 2004. Software Acquisition Best Practices: Experiences From the Space Systems Domain 37.

Ahmi, A., Saidin, S.Z., Abdullah, A., 2014. IT Adoption by Internal Auditors in Public Sector: A Conceptual Study. Procedia - Social and Behavioral Sciences, International Conference on Accounting Studies 2014, ICAS 2014, 18-19 August 2014, Kuala Lumpur, Malaysia 164, 591-599. https://doi.org/10.1016/j.sbspro.2014.11.151

Alhazmi, O., Malaiya, Y., Ray, I., 2005. Security Vulnerabilities in Software Systems: A Quantitative Perspective, in: Jajodia, S., Wijesekera, D. (Eds.), Data and Applications Security XIX, Lecture 
International Journal of Economics, Business and Accounting Research (IJEBAR)

Peer Reviewed - International Journal

Vol-4, Issue-2, 2020 (IJEBAR)

E-ISSN: 2614-1280 P-ISSN 2622-4771

https://jurnal.stie-aas.ac.id/index.php/IJEBAR

Notes in Computer Science. Springer, Berlin, Heidelberg, pp. 281-294.

https://doi.org/10.1007/11535706_21

Al-Qudah, S., Meridji, K., Al-Sarayreh, K.T., 2015. A Comprehensive Survey of Software Development Cost Estimation Studies. https://doi.org/10.1145/2816839.2816913

Antonella, E., 2016. Research 2.0 and the Impact of Digital Technologies on Scholarly Inquiry. IGI Global.

Arocena, G.A., 2012. La regulación de los delitos informáticos en el Código Penal argentino: Introducción a la Ley Nacional núm. 26.388. Boletín mexicano de derecho comparado 45, 945988.

Arriola Navarrete, O., Tecuatl Quechol, G., González Herrera, G., 2011. Software propietario vs software libre: una evaluación de sistemas integrales para la automatización de bibliotecas. Investigación bibliotecológica 25, 37-70.

Auer, A., Karjalainen, J., Seppänen, V., 1996. Improving R \& D processes by an ISO 9001-based quality management system. Journal of Systems Architecture 42, 235-244. https://doi.org/10.1016/13837621(96)00010-0

Avison, D.E., Shah, H.U., Wilson, D.N., 1994. Software quality standards in practice: the limitations of using ISO-9001 to support software development. Software Quality Journal 3, 105-111. https://doi.org/10.1007/BF00213633

Bănărescu, A., 2015. Detecting and Preventing Fraud with Data Analytics. Procedia Economics and Finance, Emerging Markets Queries in Finance and Business 2014, EMQFB 2014, 24-25 October 2014, Bucharest, Romania 32, 1827-1836. https://doi.org/10.1016/S2212-5671(15)01485-9

Birk, A., Pfahl, D., 2002. A Systems Perspective on Software Process Improvement, in: Oivo, M., KomiSirviö, S. (Eds.), Product Focused Software Process Improvement, Lecture Notes in Computer Science. Springer, Berlin, Heidelberg, pp. 4-18. https://doi.org/10.1007/3-540-36209-6_4

Brosius, A., van Elsas, E.J., de Vreese, C.H., 2019. Trust in the European Union: Effects of the information environment. European Journal of Communication 34, 57-73. https://doi.org/10.1177/0267323118810843

Cabaj, K., Kotulski, Z., Księżopolski, B., Mazurczyk, W., 2018. Cybersecurity: trends, issues, and challenges. EURASIP Journal on Information Security 2018, 10. https://doi.org/10.1186/s13635018-0080-0

Calvo-Manzano, J., Gonzalo, C., Mejia, J., San Feliu, T., Tomás, F., Rocha, Á., 2010. Evaluación de Contratos de Adquisición de Productos y Servicios de Software en Outsourcing.

Cerda Silva, A., 2011. El "nivel adecuado de protección" para las transferencias internacionales de datos personales desde la Unión Europea. Revista de derecho (Valparaíso) 327-356. https://doi.org/10.4067/S0718-68512011000100009

Cerda Silva, A., 2006. Mecanismos de Control en la Protección de Datos en Europa. Ius et Praxis 12, 221-251. https://doi.org/10.4067/S0718-00122006000200009

Chou, D.C., Yen, D.C., Chen, J.Q., 1998. Analysis of the total quality management-based software auditing. Total Quality Management 9, 611-618. https://doi.org/10.1080/0954412988307

Claver, A., 2018. Governance of cyber warfare in the Netherlands: an exploratory investigation. The International Journal of Intelligence, Security, and Public Affairs 20, 155-180. https://doi.org/10.1080/23800992.2018.1484235

Contreras Clunes, A., 2003. DELITOS INFORMÁTICOS: UN IMPORTANTE PRECEDENTE. Ius et Praxis 9, 515-521. https://doi.org/10.4067/S0718-00122003000100023

Dodd, I., Habli, I., 2012. Safety certification of airborne software: An empirical study. Reliability Engineering \& System Safety 98, 7-23. https://doi.org/10.1016/j.ress.2011.09.007

Dorling, A., 1993. SPICE: Software process improvement and capability dEtermination. Information and Software Technology, Software Process Modelling in Practice 35, 404-406. https://doi.org/10.1016/0950-5849(93)90011-Q 
International Journal of Economics, Business and Accounting Research (IJEBAR)

Peer Reviewed - International Journal

Vol-4, Issue-2, 2020 (IJEBAR)

E-ISSN: 2614-1280 P-ISSN 2622-4771

https://jurnal.stie-aas.ac.id/index.php/IJEBAR

Edwards, M.A., 2020. The Concept and Federal Crime of Mortgage Fraud. Am. Crim. L. Rev. 57, 57.

Esterkin, V., Pons, C., Esterkin, V., Pons, C., 2017. Evaluación de calidad en el desarrollo de software dirigido por modelos. Ingeniare. Revista chilena de ingeniería 25, 449-463. https://doi.org/10.4067/S0718-33052017000300449

Farbey, B., Finkelstein, A., 2001. Software acquisition: a business strategy analysis. Proceedings Fifth IEEE International Symposium on Requirements Engineering. https://doi.org/10.1109/ISRE.2001.948546

Fernández, F., Cornejo-Saavedra, E., Vogel, G., 2015. La Polar: Manipulación de los Estados Financieros, Fraude e Impacto. pp. 163-192.

Fowler, P., Rifkin, S., 1990. Software Engineering Process Group Guide (No. CMU/SEI-90-TR-24). CARNEGIE-MELLON UNIV PITTSBURGH PA SOFTWARE ENGINEERING INST.

Fujita, H., Papadopoulos, G.A., 2016. New Trends in Software Methodologies, Tools and Techniques: Proceedings of the Fifteenth SoMeT_16. IOS Press.

Garae, J., Ko, R.K.L., 2017. Visualization and Data Provenance Trends in Decision Support for Cybersecurity, in: Palomares Carrascosa, I., Kalutarage, H.K., Huang, Y. (Eds.), Data Analytics and Decision Support for Cybersecurity: Trends, Methodologies and Applications, Data Analytics. Springer International Publishing, Cham, pp. 243-270. https://doi.org/10.1007/978-3-319-594392_9

Garrett, S.G.E., Skevington, P.J., 1999. An Introduction to Electronic Commerce. BT Technology Journal 17, 11-16. https://doi.org/10.1023/A:1009612000420

Ghosh, R.A., 2007. Economic impact of open source software on innovation and the competitiveness of the Information and Communication Technologies (ICT) sector in the EU [WWW Document]. undefined. URL https://www.semanticscholar.org/paper/Economic-impact-of-open-sourcesoftware-on-and-the-Ghosh/4f0469c3702f5a22176265c72d0d764bc0447774 (accessed 4.18.20).

Gloria Piedad, G.-H., Muñoz, M., Mejia, J., Jose A., C.-M., 2014. Software Requirements Development: A Path for Improving Software Quality, in: Barafort, B., O’Connor, R.V., Poth, A., Messnarz, R. (Eds.), Systems, Software and Services Process Improvement, Communications in Computer and Information Science. Springer, Berlin, Heidelberg, pp. 194-205. https://doi.org/10.1007/978-3662-43896-1_17

Gómez, A.D., 2010. El delito informático, su problemática y la cooperación internacional como paradigma de su solución: El Convenio de Budapest. https://doi.org/10.18172/redur.4071

González G, P., 2015. Propuesta de un modelo para medir activos intangibles en empresas de software a partir de una herramienta multicriterio. Estudios Gerenciales 31, 191-201. https://doi.org/10.1016/j.estger.2014.12.002

González, R.M.D., Ruiz, M.A.G., 2018. Retos de la contabilidad y la auditoría en la economía actual: Homenaje al profesor Vicente Montesinos Julve. Universitat de València.

G.p, G.-H., J.a.e, A., M.c, G.Á., 2014. Technique for risk identification of software acquisition and information technologies, Scopus. IGI Global. https://doi.org/10.4018/978-1-4666-5182-1.ch002

Guerrero, C.A., Londoño, J.M., 2016. Revisión de la Problemática de la Calidad del Software para el Desarrollo de Aplicaciones de Computación en la Nube. Información tecnológica 27, 61-80. https://doi.org/10.4067/S0718-07642016000300007

Hammi, A., 2014. Control Financiero interno bajo incertidumbre: control de gestión de la liquidez. Hayen, R., 2004. SOFTWARE ACQUISITION AND DEVELOPMENT ALTERNATIVES: AN INVESTIGATION OF PREFERENCES. Issues in Information Systems 5.

Huh, W.T., 2001. Software process improvement: operations perspectives. PICMET '01. Portland International Conference on Management of Engineering and Technology. Proceedings Vol.1: Book of Summaries (IEEE Cat. No.01CH37199). https://doi.org/10.1109/PICMET.2001.952337

Humphrey, W.S., 1988. The software engineering process: definition and scope, in: Proceedings of the 4th International Software Process Workshop on Representing and Enacting the Software Process, 
International Journal of Economics, Business and Accounting Research (IJEBAR)

Peer Reviewed - International Journal

Vol-4, Issue-2, 2020 (IJEBAR)

E-ISSN: 2614-1280 P-ISSN 2622-4771

https://jurnal.stie-aas.ac.id/index.php/IJEBAR

ISPW '88. Association for Computing Machinery, Devon, United Kingdom, pp. 82-83. https://doi.org/10.1145/75110.75122

Isasi-Genix, A., Gómez-Acosta, M.I., Stuart-Cárdenas, M.L., 2012. Diseño del proceso de implementación de software en DESOFT Habana. Ingeniería Industrial 33, 60-68.

Isolano, A.I., 2003. Toma de decisiones gerenciales. Tecnología en Marcha 16, 44-51.

Jalote, P., 1999. CMM in Practice: Processes for Executing Software Projects at Infosys [WWW Document]. URL https://www.semanticscholar.org/paper/CMM-in-Practice\%3A-Processes-forExecuting-Software-Jalote/27f08d41392e8140530805750070729570f69554 (accessed 4.18.20).

Jang-Jaccard, J., Nepal, S., 2014. A survey of emerging threats in cybersecurity. Journal of Computer and System Sciences, Special Issue on Dependable and Secure Computing 80, 973-993. https://doi.org/10.1016/j.jcss.2014.02.005

Jorgensen, M., Shepperd, M., 2007. A Systematic Review of Software Development Cost Estimation Studies. IEEE Transactions on Software Engineering 33, 33-53. https://doi.org/10.1109/TSE.2007.256943

Klaus, H., Rosemann, M., Gable, G.G., 2000. What is ERP? Information Systems Frontiers 2, 141-162. https://doi.org/10.1023/A:1026543906354

Kruse, C.S., Frederick, B., Jacobson, T., Monticone, D.K., 2017. Cybersecurity in healthcare: A systematic review of modern threats and trends. Technology and Health Care 25, 1-10. https://doi.org/10.3233/THC-161263

Lara, R.R.R., Lapeña, O.L., Alcalá, J.M., 2001. Software y hardware del C8XC251 : problemas [WWW Document]. URL https://www.semanticscholar.org/paper/Software-y-hardware-del-C8XC251\%3A-problemas-Lara-Lape\%C3\%B1a/7b3742d9eb268653771a41893280bcd70f974987 (accessed 4.18.20).

Lavarda, C.E.F., Feliu, V.M.R., Palanca, M.B., 2009. La Interiorización del cambio de un sistema Contable de Gestión en la pequeña empresa. Revista Contabilidade \&amp; Finanças 20, 101-115. https://doi.org/10.1590/S1519-70772009000300007

Liberona, D., Ruiz, M., 2013. Análisis de la implementación de programas de gestión del conocimiento en las empresas chilenas. Estudios Gerenciales 29, 151-160. https://doi.org/10.1016/j.estger.2013.05.003

López, E.B., Barbadillo, E.R., Aguilar, N.G., 2011. ¿Cómo actúan las empresas frente a la dependencia económica del auditor?: el papel del comité de auditoría. Revista de Contabilidad 14, 87-119. https://doi.org/10.1016/S1138-4891(11)70023-1

Madec, M., Lallement, C., Haiech, J., 2017. Modeling and simulation of biological systems using SPICE language. PLOS ONE 12, e0182385. https://doi.org/10.1371/journal.pone.0182385

Manwadkar, M., 2018. Automated Web Based Test Engine Using Cloud. IJRASET 6, 3656-3660. https://doi.org/10.22214/ijraset.2018.4609

Marín Sánchez, J., Lugo García, J.A., 2016. Control de proyectos de software: actualidad y retos para la industria cubana. Ingeniare. Revista chilena de ingeniería 24, 102-112. https://doi.org/10.4067/S0718-33052016000100010

Martelo, R.J., Jiménez-Pitre, I., Moncaris González, L., 2017. Guía Metodológica para el Mejoramiento del Desarrollo de Software a través de la Aplicación de la Técnica Árboles de Problemas. Información tecnológica 28, 87-94. https://doi.org/10.4067/S0718-07642017000300010

Masaeli, M., Bula, G., Harrington, S.E., 2019. Latin American Perspectives on Global Development. Cambridge Scholars Publishing.

Matende, S., Ogao, P., 2013. Enterprise Resource Planning (ERP) System Implementation: A Case for User Participation. Procedia Technology, CENTERIS 2013 - Conference on ENTERprise Information Systems / ProjMAN 2013 - International Conference on Project MANagement/ HCIST 2013 - International Conference on Health and Social Care Information Systems and Technologies 9, 518-526. https://doi.org/10.1016/j.protcy.2013.12.058 
International Journal of Economics, Business and Accounting Research (IJEBAR)

Peer Reviewed - International Journal

Vol-4, Issue-2, 2020 (IJEBAR)

E-ISSN: 2614-1280 P-ISSN 2622-4771

https://jurnal.stie-aas.ac.id/index.php/IJEBAR

Mayer Lux, L., Mayer Lux, L., 2018. Elementos criminológicos para el análisis jurídico-penal de los delitos informáticos. Ius et Praxis 24, 159-206. https://doi.org/10.4067/S071800122018000100159

Mejía-Neira, Á., Jabba, D., Caballero, G.C., Caicedo-Ortiz, J., Mejía-Neira, Á., Jabba, D., Caballero, G.C., Caicedo-Ortiz, J., 2019. Influencia de la Ingeniería de Software en los Procesos de Automatización Industrial. Información tecnológica 30, 221-230. https://doi.org/10.4067/S071807642019000500221

Nahabetián Brunet, L., 2015. Protección de datos y gestión documental: Decálogo ampliado para la sociedad de la información. Revista de la Facultad de Derecho 9-9.

Niazi, M., 2006. Software Process Improvement: A Road to Success, in: Münch, J., Vierimaa, M. (Eds.), Product-Focused Software Process Improvement, Lecture Notes in Computer Science. Springer, Berlin, Heidelberg, pp. 395-401. https://doi.org/10.1007/11767718_34

Oliva, R., Carvajal, K., Cataldo, A., Oliva, R., Carvajal, K., Cataldo, A., 2018a. Impacto de TI en las pequeñas y medianas empresas ies su efecto moderado por la intensidad de uso de TI de la industria? Journal of technology management \&amp; innovation 13, 82-93. https://doi.org/10.4067/S0718-27242018000200082

Oliva, R., Carvajal, K., Cataldo, A., Oliva, R., Carvajal, K., Cataldo, A., 2018b. Impacto de TI en las pequeñas y medianas empresas $i$ es su efecto moderado por la intensidad de uso de TI de la industria? Journal of technology management \&amp; innovation 13, 82-93. https://doi.org/10.4067/S0718-27242018000200082

Paulk, M.C., 1995. How ISO 9001 Compares With The CMM.

Quesada Sevilla, A., Zamora Fonseca, R., Brito Brito, A., 2016. Propuesta de mejoras para el proceso de gestión de la información bibliográfica en la Universidad de Cienfuegos. Revista Universidad y Sociedad 8, 57-64.

Quintanilla, B., Isabel, T., 2013. Estado situacional de la protección de datos personales en Chile, regulación jurídica y alcances.

Quispe-Otacoma, A.L., Padilla-Martínez, M.P., Telot-González, J.A., Nogueira-Rivera, D., 2017. Tecnologías de información y comunicación en la gestión empresarial de pymes comerciales. Ingeniería Industrial 38, 81-92.

Razón, O.C., Durán, J.G., González, J.A.G., Cortés, F.I., Miranda, J.M., 2014. Cómo Guiar a las Pymes en la Mejora de Procesos Software. RISTI - Revista Ibérica de Sistemas e Tecnologias de Informação 17-30. https://doi.org/10.4304/risti.e1.17-30

Recker, J., 2012. BPMN Research: What We Know and What We Don't Know, in: Mendling, J., Weidlich, M. (Eds.), Business Process Model and Notation, Lecture Notes in Business Information Processing. Springer, Berlin, Heidelberg, pp. 1-7. https://doi.org/10.1007/978-3-642-33155-8_1

Rehman, S., Mustafa, K., 2009. Research on software design level security vulnerabilities. SOEN. https://doi.org/10.1145/1640162.1640171

Respício, A., Domingos, D., 2015. Reliability of BPMN Business Processes. Procedia Computer Science, Conference on ENTERprise Information Systems/International Conference on Project MANagement/Conference on Health and Social Care Information Systems and Technologies, CENTERIS/ProjMAN / HCist 2015 October 7-9, 2015 64, 643-650. https://doi.org/10.1016/j.procs.2015.08.578

Riascos-Erazo, S.C., Arias-Cardona, V.H., n.d. Análisis del impacto organizacional en el proceso de implementación de los Sistemas de Información ERP-Caso de Estudio. Entramado 12, 284-302.

Ronquillo, J.G., Erik Winterholler, J., Cwikla, K., Szymanski, R., Levy, C., 2018. Health IT, hacking, and cybersecurity: national trends in data breaches of protected health information. Jamia Open 1, 1519. https://doi.org/10.1093/jamiaopen/ooy019

Roselló Gallardo, V., 2017. ¿Cómo enfrentar la selección de un sistema de información contable? Cofin Habana 11, 281-294. 
International Journal of Economics, Business and Accounting Research (IJEBAR)

Peer Reviewed - International Journal

Vol-4, Issue-2, 2020 (IJEBAR)

E-ISSN: 2614-1280 P-ISSN 2622-4771

https://jurnal.stie-aas.ac.id/index.php/IJEBAR

Ross, D.T., Goodenough, J.B., Irvine, C.A., 1975. Software Engineering: Process, Principles, and Goals. Computer 8, 17-27. https://doi.org/10.1109/C-M.1975.218952

Sacha, K., n.d. Software Engineering Practices: An Auditor's Perspective 16.

Salguero, S., Javier, F., 2016. Relación entre la protección de los datos personales y el derecho de acceso a la información pública dentro del marco del derecho comparado. Ius et Praxis 22, 323-376. https://doi.org/10.4067/S0718-00122016000100010

Solimano, A., 2012. Chile and the Neoliberal Trap: The Post-Pinochet Era. Cambridge University Press.

Sommerville, I., 2005. Ingeniería del software. Pearson Educación.

Stålhane, T., Hanssen, G.K., 2008. The Application of ISO 9001 to Agile Software Development, in: Jedlitschka, A., Salo, O. (Eds.), Product-Focused Software Process Improvement, Lecture Notes in Computer Science. Springer, Berlin, Heidelberg, pp. 371-385. https://doi.org/10.1007/978-3-54069566-0_30

Stamelos, I., Angelis, L., Morisio, M., Sakellaris, E., Bleris, G.L., 2003. Estimating the development cost of custom software. Inf. Manag. https://doi.org/10.1016/S0378-7206(02)00099-X

Surakhi, O.M., Hudaib, A., Alshraideh, M., Khanafseh, M., 2017. A Survey on Design Methods for Secure Software Development, in: BIOINFORMATICS 2017. https://doi.org/10.24297/ijct.v16i7.6467

Tangpong, C., Islam, M., Lertpittayapoom, N., 2009. The Emergence of Business-to-Consumer ECommerce: New Niche Formation, Creative Destruction, and Contingency Perspectives. Journal of Leadership \& Organizational Studies. https://doi.org/10.1177/1548051809338054

Tupe, S.K., Sayyad, S.B., Behre, S., 2009. Comparative Study of Different Spice Software's Using Astable Multivibrator in Different Spice Software [WWW Document]. undefined. URL https://www.semanticscholar.org/paper/Comparative-Study-of-Different-Spice-Software's-in-TupeSayyad/ba245e4a7fc1d7aa48bd3400c18cfc77a069de8c (accessed 4.18.20).

Uzelac, A., 2008. How to understand digital culture: Digital culture - a resource for a knowledge society? pp. 7-21.

Valencia Duque, F., 2015. La auditoría continua, un modelo complementario que permite agregar valor a la auditoría moderna.

Vergara Rojas, M., Vergara Rojas, M., 2017. Chile: Comentarios preliminares al proyecto de ley que regula la protección y tratamiento de datos personales y crea la Agencia de Protección de Datos Personales. Revista chilena de derecho y tecnología 6, 135-152. https://doi.org/10.5354/07192584.2017.45822

Villar, A.G.C., 2020. Control integrado de gestión y su influencia en la toma de decisiones en Importaciones Hiraoka S.A.C. Business Innova Sciences 1, 32-42.

Walker, A.J., 1998. Improving the quality of ISO 9001 audits in the field of software. Information and Software Technology 40, 865-869. https://doi.org/10.1016/S0950-5849(98)00104-9

Zelkowitz, M., 1978. Perspectives in Software Engineering. ACM Comput. Surv. 10, 197-216. https://doi.org/10.1145/356725.356731 